УДК 347.6(477):340.12

DOI https://doi.org/10.32849/2663-5313/2021.3.11

\title{
Олександр Соболєв,
}

канд. юрид. наук, дочент,

доцент кафедри иивільного права та процесу

факультету № 6

Харківського начіонального університету внутрішніх справ

\section{ПРАВО НА БАТЬКІВСТВО ТА МАТЕРИНСТВО: ВИКЛИКИ ЧАСУ}

Стаття присвячена розгляду проблемних питань зовнішнього впливу на особисті немайнові права подружжя щодо здійснення дружиною та чоловіком свого права на материнство та батьківство. Установлено, що до таких факторів зовнішнього впливу належать складний матеріальний стан подружжя, бажання одиноких осіб або подружжя досягнути поставленої мети шодо певного стабільного становища в суспільстві, яка, на їхню думку, може бути обумовлена народженням чи не народженням дитини. Особливо важливим фактором, що з'явився останнім часом, є проблема глобального потепління, яку в тому числі пов'язують зі зростанням народонаселення.

На підставі історичних даних доведено, що протягом досить тривалого часу неабиякий вплив на демографічний розвиток суспільства чинила бідність певного прошарку населення. Це призводило до небажання подружжя мати дітей узагалі або скорочувати їх кількість у сім'ях. Цікавим є приклад, як ще на початку XX сторіччя жінки вдавалися навіть до магічних дій з метою недопущення народження дитини. У подальшому в статті наведено історичні факти щодо становлення інституту абортів у суспільстві (стосовно дозволів і заборони їх проведення).

Доведено, що й діаметрально протилежнии стан особи чи подружжя (належність до соиіально захищених верств населення) також негативно впливає на здійснення останніми свого немайнового права на материнство та батьківство. Підставою для иього є небажання «втратити» свій статус у суспільстві або, навпаки, не досягти бажаного.

Звернуто увагу, що неабиякий вплив на здійснення прав на материнство та батьківство має й актуальна сьогодні проблема, яка з'явилася останнім часом, а саме проблема глобального потепління, що, на думку деяких фахівиів, пов'язана зі збільшенням народження дітей.

Висновки роботи базуються на тому, що, незважаючи на певні зовнішні умови, які впливають на здійснення дружиною або чоловіком свого права на материнство чи батьківство, кожен із подружжя сам повинен вирішувати долю існування своєї сім'ї.

Ключові слова: філософія права, особисті немайнові права, право на материнство, право на батьківство, соціальні умови, глобальне потепління.

Постановка проблеми. Статті 49, 50 Сімейного кодексу України від 10 січня 2002 року до особистих немайнових прав подружжя зараховують право на материнство та право на батьківство, передбачаючи, що дружина має право на материнство, а чоловік має право на батьківство. Небажання чоловіка мати дитину або нездатність його до зачаття дитини може бути причиною розірвання шлюбу. Такі ж наслідки тягне за собою відмова дружини від народження дитини або нездатність іï до народження дитини. При цьому право дружини на материнство та право чоловіка на батьківство означає як право мати дитину, так і право не мати дитини, утриматися від народження дітей. Такі положення сімейного законодавства про причину розірвання шлюбу в разі небажання дружини, чоловіка мати дітей або нездатності до народження дитини можуть свідчити про обмеження свободи поведінки жінки та чоловіка в шлюбі.

Висловлюється думка, що материнство та батьківство є базовим життєвим призначенням, закладеним і сформованим самою природою [1, с. 280]. Прикро констатувати той факт, що сьогодні материнство та батьківство втратило колишню ціннісну орієнтацію як підстави, що становить зміст буття сучасних жінки та чоловіка. Передусім це стосується катастрофічного зниження народження дітей в Україні. Статистичні дані підтверджують цю «сумну» статистику. Так, у 1989 році в Україні народилося 690981 дітей, у 1991 році - 630813 дітей, у 2001 році - 376478 дітей, у 2019 році 308817 дітей (без урахування народження дітей на тимчасово окупованих територіях) [2]. Аналізуючи наведені статистичні дані про народження дітей в Україні 
за останні тридцять років, можна зробити висновок, що кількість новонароджених скоротилася більше ніж у два рази. I це не може не турбувати.

Неабияким чинником у цьому випадку $\epsilon$ певні зовнішні соціальні умови, які впливають на життя сім'ї. Варто зазначити, що вказані умови можуть не тільки формувати та розвивати подружжя, а й пригнічувати, знищувати природні задатки й здібності, призводити до заперечення дітородних функцій, зміни традиційних соціальних ролей жінки та чоловіка в суспільстві.

Проблемні питання здійснення права на материнство та права на батьківство привертали увагу таких правників: Ю.В. Драгомирова [3, с. 56-59], О.В. Ієвіня [4, с. 97-100], В.Ю. Москалюк [5, с. 124-129] та ін. Але в дослідженнях у більшості своїй вони зверталися до сімейно-правових і цивільно-правових аспектів здійснення цих особистих немайнових прав, не досліджуючи ретельно фактори зовнішнього впливу на здійснення права на батьківство та права на материнство.

Метою статті $є$ вивчення наслідків впливу певних соціальних факторів (бідність, прагнення до багатства, розкішного життя), екологічних факторів (наприклад, глобальне потепління) на здійснення подружжям особистого немайнового права на материнство та на батьківство, передбачених Сімейним кодексом України.

Виклад основного матеріалу. Однією із суттєвих умов, яка впливає на бажання батьків народжувати дітей, є соціальна незахищеність деякої частки населення, іншими слова, іiі бідність. Охарактеризувати цей феномен можна так. Бідною можна вважати людину, рівень прибутків якої не дає їй змоги отримати певний фізіологічно необхідний мінімум життєвих благ, такий як продукти харчування, одяг, послуги, можливість надати дітям гідну освіту, а дорослим - підвищити свою кваліфікацію, тобто загалом забезпечити собі «базову» без надлишків якість життя.

У 1798 році Томас Мальтус написав найбільш відоме есе «Досвід закону про народонаселення», яке також широко відоме як мальтузіанська пастка [6]. Узагалі так звана мальтузіанська пастка визначається як формальне слідство 3 теорії Мальтуса, згідно з якою зростання населення випереджає зростання виробництва, так як динаміка зростання населення спостерігається в геометричній, а виробництва - в арифметичній прогресії. Звідси випливає, що людство перебуває в пастці, воно приречене на безробіття, голод, зубожіння широких мас, якщо не буде налагоджено регулювання народжуваності
[7, с. 265]. Мальтузіанська пастка стверджує, що в міру зростання населення світ не зможе підтримувати виробництво сільськогосподарських культур, щоб прогодувати населення, яке постійно зростає.

Наприкінці XVIII сторіччя, мешкаючи в Англії, Т. Мальтус став свідком зниження рівня життя в міру зростання народжуваності серед бідних. На підставі зроблених висновків він виступав за регулювання народжуваності, яке полягало в тому, щоб бідні родини ніколи не народжували дітей, яких би вони не змогли утримувати. Також він указував на те, що причина бідності суспільства нижчого прошарку населення полягає в його ж безвідповідальності.

Навряд чи саме ці думки Т. Мальтуса були достатньо розповсюдженими серед бідної частини українського суспільства. Але, як свідчить історія, на українських землях контролю народжуваності бідні сім'ї приділяли достатньо уваги.

Складні соціальні умови досить глибоко торкнулися основ материнства та батьківства соціально незахищених верств населення за часів середини XIX - початку XX ст., що потягло за собою відмову подружжя мати дітей у шлюбі. Із цього приводу хочеться навести таке: «А як же той повинен мудрувати, котрому приходитця жить всего тіко на одній півдесятині? От він і вигадує собі, шоб самому не мучиця на цім світі і діти шоб не терпіли ще більшої муки як він» [8, с. 120].

Проводячи екскурс в історію, необхідно зазначити, що випадки регулювання вагітності (контрацепція, не аборти!) були відомі ще в стародавніх у більшості своїй бідних українських сім'ях. Цікавий приклад наводить кандидат історичних наук I.B. Ігнатенко, яка зазначає, що контрацептивні засоби, які застосовували жінки в традиційному українському суспільстві, умовно можна розподілити на два види: раціональні (уживання відварів трав, коріння тощо) та ірраціональні (магічні). Також авторка схиляється до думки, що частіше застосовували саме магічні засоби контрацепції, і зазначає: «Зокрема, жінки їли хліб із шерстю ялової корови чи вівці. У цьому разі ялова корова мала «передати» свою безплідність жінці. Вважали, що дітей не буде й тоді, коли дати з'їсти плаценту свині. Окрім того, вірили, якщо три дні не ховати послід (плаценту), то три роки не буде дітей. Щоб уникнути нової вагітності, жінки також намагалися якомога довше годувати дитину груддю» [9, с. 226-227]. Зрозуміло, що зазначені засоби уникнути вагітності сьогодні можна сприйняти тільки як цікаві факти з історії українського суспільства. 
Сьогодні в контексті здійснення права на материнство, крім застосування контрацептивних засобів щодо недопущення народження дитини, розглядається також проблема аборту, тобто штучного переривання вже наявної вагітності [10, с. 114].

Проблема абортів завжди була актуальною в суспільстві. У різні часи розвитку суспільства на законодавчому рівні дозволялося або заборонялося штучне переривання вагітності.

У перші роки після громадянської війни та озброєної інтервенції в зв'язку з економічною розрухою в державі 18 листопада 1920 року було дозволено проведення абортів, доки «моральні пережитки минулого й тяжкі економічні умови сьогодення ще змушують частину жінок зважитися на цю операцію». 27 червня 1936 року Постановою ЦВК та РНК СРСР у зв'язку з установленою шкідливістю абортів було заборонено проведення таких як у лікарнях і спеціальних медичних закладах, так і на дому в лікарів i на приватних квартирах вагітних. Проведення абортів дозволялося лише в тих випадках, коли продовження вагітності становило загрозу життю чи загрожувало тяжкими наслідками здоров'ю вагітної жінки, а так само за наявності тяжких захворювань батьків, які могли бути передані в спадок, виключно в обстановці лікарень і пологових будинків. За проведення абортів з порушенням вимог закону була передбачена кримінальна відповідальність. 23 грудня 1955 року заборона на проведення абортів була скасована на законодавчому рівні [11, с. 33-35].

Сьогодні, згідно зі ст. 50 Основ законодавства України про охорону здоров'я від 19 листопада 1992 року, операція штучного переривання вагітності (аборт) може бути проведена за бажанням жінки в закладах охорони здоров'я при вагітності строком не більше ніж 12 тижнів. У випадках, установлених законодавством, штучне переривання вагітності може бути проведене при вагітності від дванадцяти до двадцяти двох тижнів [12]. Ураховуючи наведене, необхідно зазначити, що саме жінка самостійно вирішує питання щодо проведення аборту чи ні. Тобто вона сама вирішує, здійснювати своє право на материнство чи ні. Логічно виникає питання: як у такому разі батько може здійснювати своє право на батьківство, якщо, згідно з наведеними законодавчими положеннями, його згода на штучне переривання вагітності жінкою не враховується? До такої позиції законодавця критично ставиться 3.В. Ромовська, яка вказує: «Складається парадоксальна ситуація: для продажу одним 3 подружжя автомобіля потрібна згода дру- гого, а питання проведення штучного переривання вагітності дружина має право вирішувати своєвільно» [13, с. 153].

Розглядаючи проблему планування сім'ї, пов'язану з рівнем економіки в державі, варто зазначити, що в деяких країнах запропоновані досить радикальні заходи. Так, Санджай Ганді свого часу висловлював думку стосовно того, що контроль народжуваності має бути невід'ємною частиною плану розвитку Індій. За його словами, програмі планування сім'ї потрібно надати «найпильнішої уваги й значення, тому що всі наші промисловості, економічні та сільськогосподарські успіхи не принесуть жодної користі, якщо населення й надалі зростатиме нинішніми темпами». Фактично він пропонував застосування примусової стерилізації під час надзвичайної ситуації [14, с. 123, 304].

Характеризуючи ситуацію в країні та вплив її на створення повноцінної сім'ї та народження дітей, хочеться знову звернутися до думки 3.В. Ромовської, яка ще у 2003 році зазначала: «Нинішня ситуація в Україні дещо нагадує повоєнну - економічна криза, низький рівень життя, зростаюче безробіття основної маси населення... Нестатки, економічна залежність позбавили велику кількість жінок та чоловіків можливості вибору форми свого сімейного життя. I вони згоджуються на будь-які умови, щоб вижити» [10, с. 165]. На жаль, за минулий час суттєвих позитивних змін у країні не відбулося.

Але не тільки соціально незахищені верстви населення відмовляються від створення сім'ї та народження дітей. Сьогодні в суспільстві серед деяких громадян розповсюдженою є думка, що сім'я, народження й виховання дітей є досить серйозною перешкодою на шляху до досягнення своєї мети в житті. На жаль, прихильників цієї думки стає все більше. Отримання високого статусу в суспільстві, високооплачуваної роботи, як наслідок, дорогі розваги й дозвілля останнім часом стали пріоритетними цінностями людства. Планування сім'ї та народження дітей відійшло від пріоритетних напрямів суспільства. До небезпеки знищення подружніх і родинних цінностей майже неминуче додається й інша небезпека, а саме зниження народження дітей [15, с. 206-207]. Плюмар де Дангель зазначав, що бажання до розкоші призвело до зниження кількості шлюбів навіть серед забезпечених людей. Багато людей залишаються неодруженими, тому що більш престижно мати в конюшні шістьох коней, ніж подарувати державі шість дітей і жити скромно [15, с. 207]. Особливо це стосується так званої «золотої молоді». Але не 
тільки ці верстви населення відмовляються від створення сім'ї та народження дітей. Люди, які не потрапили до цього соціального прошарку населення, але кожен день мріють про це, також не поспішають обзаводитися повноцінною сім'єю.

Суттєвим зовнішнім соціальним впливом, який також певним чином впливає на створення й існування сім'ї та можливість мати дітей, $\epsilon$ досить актуальний останнім часом фактор глобального потепління. Логічно припустити, що подібні побоювання повинні неминуче позначитися на питанні планування сім'ї. Саме це вже відбувається в країнах Свропи та США серед забезпеченої молоді, яка репродуктивні питання часто пов’язує з політикою [16, с. 178]. Сьогодні тема глобального потепління та, як наслідок, виникнення кліматичних війн і в подальшому загибель цивілізації загалом усе більше стає предметом політичних дебатів. У зв’язку 3 цим багато молоді всерйоз замислюється над тим, чи варто народжувати дітей у напівзруйнованому світі, повному страждань. Дітей, які зможуть тільки погіршувати кліматичну проблему своєю появою, ставши новими споживачами ресурсів [16, с. 178]. Ще у 2011 році Гвінн Дайєр зазначав: «Нас зараз так багато, і ми споживаємо стільки, що планета повинна бути відсотків на тридцять більше, щоб забезпечити нашу життєздатність. Якщо б решта світу підтримувала «західний» рівень життя, нам би треба було три-чотири таких планети» [17, с. 12].

Газета The Guardian у 2017 році опублікувала статтю під назвою «Бажаєте зупинити зміни клімату? Народжуйте менше дітей» [17], у газеті The New York Times з'явилася стаття «Додайте це в список запитань, що викликані зміною клімату: Чи варто заводити дітей?» [16, с. 179].

Цікавим $є$ те, що газета The Guardian, згідно 3 новими дослідженнями, до найбільш ефективних засобів скорочення викидів вуглекислого газу на перше місце ставить необхідність народження в сім'ї хоча б на одну дитину менше. I тільки до наступних заходів зараховується продаж автомобіля, відмова від тривалих перельотів і вегетаріанська дієта.

Наявність у сім'ї на одну дитину менше заощадить 58,6 тони еквівалента $\mathrm{CO}_{2}$ на рік [18].

Гвінн Дайєр зазначає: «Наші витрати енергії на душу населення великі понад усяку міру і продовжують зростати принаймні протягом життя ще двох поколінь. Сдиний спосіб привести нашу чисельність до більш-менш «стійкої» цифри - масова загибель через голод, війни та хвороби» [17, с. 293]. Звісно, щоб запобігти цим крайнім заходам, і пропонується, як уже зазначалося вище, зменшення народження дітей у сім'ях або відмова від їх народження зовсім. Досі це звучить як пропозиція засобів масової інформації, але хто дасть гарантію, що в найближчому майбутньому це не стане нормою існування людства та, як наслідок, не призведе до певних законодавчих вимог. У цьому випадку доречно навести слова Леона Фьорта - викладача теорії міжнародних відносин в Університеті Джорджа Вашингтона: «У міру наростання рівня загрози (мається на увазі глобальне потепління - O.C.) рішення будуть усе більш радикальними: морально нестерпними для тих, хто повинен їх приймати й виконувати, а в підсумку - такими, що знищують усяку мораль» [17, с. 41].

\section{Висновки}

Підсумовуючи, необхідно зазначити, що в сучасних умовах розвитку суспільства на здійснення права на материнство та батьківство, передбаченого чинним сімейним законодавством України, має вплив ціла низка певних соціальних факторів, які тим чи іншим чином обумовлюють вирішення чоловіком і дружиною питання щодо здійснення ними права на батьківство та права на материнство. До таких факторів доцільно зарахувати соціальну незахищеність, нестерпну жагу до кар'єри, грошей, вплив кліматичних змін, узагалі небажання нести певну відповідальність, пов'язану зі створенням сім'і та народженням і вихованням дітей. Зазначені фактори є вагомою перешкодою до здійснення подружжям свого права стати матір'ю та батьком дитини.

Незважаючи на це, варто зазначити, що здійснення проголошеного законодавством України права на материнство та батьківство в кінцевому підсумку залежить саме від дружини та чоловіка особисто.

\section{Список використаних джерел:}

1. Кизилова С.А., Ращикулина Е.Н. Ценности материнства и отцовства: подходы к определению. Политика, экономика и сочиальная сфера: проблемы взаимодействия. 2016. № 2. С. 280-284.

2. Населення України. Державна служба статистики України. URL: http://database.ukrcensus. gov.ua/MULT/Dialog/statfile_c.asp (дата звернення: 25.11.2020).

3. Драгомирова Ю.В. Право на материнство та батьківство як особисті немайнові права подружжя. Часопис иивілістики. 2016. Вип. 21. С. 113.

4. Ієвіня О.В. Право на материнство та батьківство як особисті немайнові права подружжя. Університетські наукові записки. 2011. № 2 (38). С. 484. 
5. Москалюк В.Ю. Право на материнство (батьківство) за Сімейним кодексом України Наукові засади та практика застосування нового Сімейного кодексу України : матеріали Круглого столу, 25 травня 2006 р., м. Київ. Харків : Ксилон, 2007. C. $124-129$.

6. Мальтус Т.Р. Опыт закона о народонаселении / перевод И.А. Вернера. Москва : Издание К.Т. Солдатенкова, 1895. 250 с.

7. Райзберг Б.А. Современный социоэкономический словарь. Москва : ИНФРА-М, 2009. 629 с

8. Грушевський М., Кузеля 3. Дитина у звичаях і віруваннях українського народу. Репр. вид. 1906 р. Київ : Інтелектуальна книга, 2017. 234 с.

9. Ігнатенко I.В. Шлюбно-сімейні стосунки у традиційній культурі українців. Харків : Книжковий Клуб «Клуб Сімейного Дозвілля», 2017. 240 с.

10. Ромовська 3.В. Сімейний кодекс України науково-практичний коментар. Київ : Видавничий Дім «Ін Юре», 2003. 532 с.

11. Кодекс законов о семье, опеке, браке и актах гражданского состояния Украинской ССР. Москва : Государственное издательство юридической литературы, 1954. 104 с.
12. Основи законодавства України про охорону здоров’я від 19 листопада 1992 року № 2801XII. Відомості Верховної Ради Украйни. 1993. № 4. CT. 19.

13. Ромовська 3.В. Українське сімейне право : підручник для студ. вищ. навч. закл. Київ : Правова єдність, 2009. 500 с.

14. Бенерджі Абхіджіт, Дуфло Естер. Економіка бідності. Як звільнити світ від злиднів / пер. 3 англ. В. Плискін. Київ : Наш формат, 2018. 312 с.

15. Перро Филипп. Роскошь: Богатство между пышностью и комфортом в XVIII-XIX веках / пер. с фр. А.Н. Смирновой. Санкт-Петербург : Издательство Ивана Лимбаха, 2014. 288 с.

16. Уоллес-Уэллс Д. Необитаемая Земля. Жизнь после глобального потепления / пер. с английского М. Финогенова. Москва : Индивидуум, 2020. 320 c.

17. Гвинн Дайер. Климатические войны / пер. с англ. В. Гончарова, А. Немировой. Москва : АСТ : Астрель ; Владимир : ВКТ, 2011. 317 с.

18. Carrington D. Want to Fight Climate Change? Have Fewer Children. The Guardian. 2017. 12 July.

Oleksandr Soboliev. The right to paternity and maternity: current challenges

The article is focused on the consideration of problematic issues of external influence on personal non-property rights of spouses in relation to a wife and a husband's realization of the right to maternity and paternity. It has been established that such factors of external influence include the difficult financial situation of the spouses, the desire of single people or spouses to achieve the goal of a certain stable position in society, which, in their opinion, may be due to the birth or non-birth of a child. A particularly important factor that has recently emerged is the problem of global warming, which is also associated with the growth of population.

Based on historical data, the author has proved that poverty of a certain layer of the population had for a long time the influence on the demographic development of society. That led to the spouses' reluctance to have children at all or to reduce their number in families. An interesting example is how women even resorted to magical acts to prevent the birth of a child in the early XX century. The author of the article has later presented historical facts about the formation of the institution of abortion in society (regarding abortions' permits and prohibitions).

It has been proved that the diametrically opposite condition of a person or spouses (belonging to socially protected segments of the population) also negatively affects the realization of the latter's inalienable right to maternity and paternity. The reason for this is the unwillingness to "lose" their status in society or, in contrast, not to achieve the desired.

Special attention of the author has been emphasized on the current and relevant problem, which has recently emerged, namely the problem of global warming, which, according to some experts, is associated with an increase in the birth of children, has a significant impact on the realization of the right to maternity and paternity.

The conclusions of the work are based on the fact that, despite certain external conditions, which affect the realization of the right of a wife or a husband to maternity or paternity, each spouse must decide the fate of own family.

Key words: philosophy of law, personal non-property rights, right to maternity, right to paternity, social conditions, global warming. 